\author{
S.V. Voronenko \\ Kherson State Maritime Academy, Ukraine \\ (E-mail:vr.sergey@ukr.net)
}

\title{
Research of possibilities of characteristics and parameters increase of asynchronous machines
}

\begin{abstract}
Improving the efficiency and reliability of ship electric power systems is a priority task for modern shipbuilding. One of the ways to solve this problem is to use the power of the main power plant for the production of electricity. In this case, it is advisable to give preference to asynchronous machines as the simplest in production and reliable in operation. It should also be noted that the asynchronous machine can be made with a massive ferromagnetic rotor or a sleeve with the use of nanotechnology, which will improve the energy parameters and performance of the electrical machine and the system as a whole. The article analyzes the characteristics of the device and the operation of an asynchronous machine (AM) with a short-circuited rotor with a ferromagnetic sleeve. Dependence of AM parameters and characteristics on the geometric dimensions of the sleeve is shown, and a technique for their determination using the system of Maxwell differential equations is proposed. An algorithm for calculating the characteristics of an AM machine and the equivalent parameters of a ferromagnetic sleeve is developed.
\end{abstract}

Keywords: asynchronous machine, rotor, ferromagnetic sleeve, slip, equivalent active and inductive resistances.

\section{Introduction}

Target setting. The modern stage of development of shipbuilding is characterized by an increase in the efficiency and reliability of ship power systems. One of the main directions of an increase in the efficiency is the improvement of waste-heat recovery system, including heat recovery of exhaust gases of main and auxiliary diesel engines using turbochargers with built-in electric machines [1]. Taking into account high speeds of rotation of turbochargers as electric machines in these systems it is expedient to use machines with a massive ferromagnetic rotor or with a ferromagnetic sleeve. At the same time, the efficiency of exhaust gas heat recovery is improved, and the operation of the compressor in different operating modes of the diesel engine is improved.

Analysis of basic researches and publications. Applications of integral turbocharger systems using an electric machine with permanent magnets, as well as asynchronous machines with a short-circuited rotor are known $[2,3]$. At the same time, the problematic issues are ensuring the mechanical strength of the rotor and problems of regulating the voltages and powers of electric machines [4]. The solution of the above problems is greatly simplified by using asynchronous machines with a massive ferromagnetic rotor using nanotechnologies in the design of ferromagnetic sleeves. Regulation of voltages, frequencies and powers in such systems is provided by means of semiconductor frequency converters.

Objective of the work is to analyze the characteristics of asynchronous machines with a ferromagnetic sleeve and to develop an algorithm for determining the parameters of the sleeve and calculating the operating characteristics of machines.

\section{Materials, methods and results of research}

Improvement of reliable and mass-dimension characteristics of asynchronous machines can be achieved by applying a special design rotor with frequency-dependent parameters, including using nanotechnology. One of the directions of the solution of such a problem can be the use of a rotor with a ferromagnetic sleeve [3, 5]. In such a design, the length of a conventional short-circuited rotor pack is $20-35 \%$ greater than the active length of the stator pack. The elongated part of the rotor is pressed with a sleeve with soft magnetic steel (Fig. 1). 


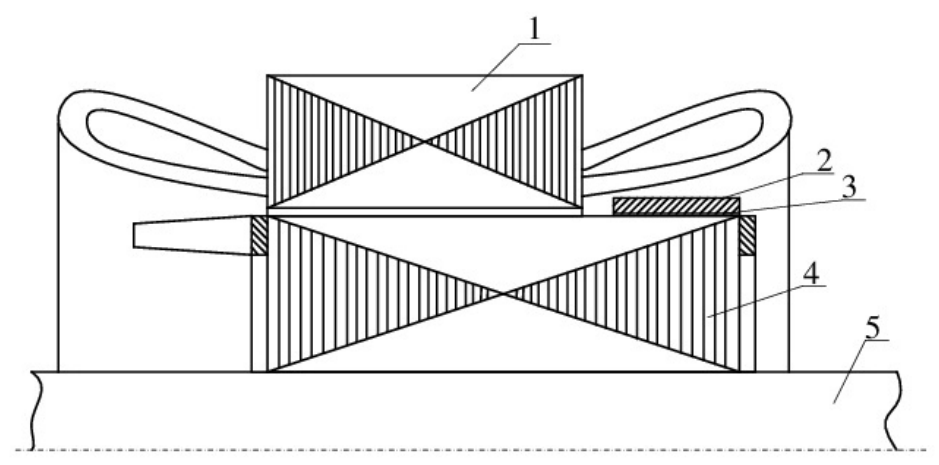

1 - stator, 2 - ferromagnetic sleeve, 3 - dielectric interval, 4 - rotor with short-circuit winding, 5 - shaft

Figure 1. The design of a rotor with a ferromagnetic sleeve

A distinctive feature of this design is that the ferromagnetic sleeve is placed under the frontal parts of the stator winding and it does not require an increase in the overall length of the machine. The processes of energy conversion in the AM of the proposed design proceeds in the same way as in the AM of the standard design but the difference consists in the following. The main magnetic flux of the machine induces an electromotive force $\dot{E}_{2}$ in the rotor winding, under the action of this EMF, a current $\dot{I}_{2}$ flows in the rotor winding, creating a magnetic flux going through the circuit: a massive sleeve, rotor clutch, a rotor back. The resulting magnetic flux passing through this circuit and formed by the combined action of the MMS of rotor winding and the eddy currents of the massive sleeve leads to an EMF $\dot{E}_{5}$ in the rotor winding. This EMF significantly limits the current flowing in the short-circuited rotor winding, and leads to a significant reduction in the starting current. This EMF can be represented as a sum of two components, which are voltage drops on the equivalent active $r_{5}$ and inductive $x_{5}$ resistances of a massive sleeve:

$$
-\dot{\mathrm{E}}_{5}=r_{5} \dot{I}_{2}+j x_{5} \dot{I}_{2}
$$

Thus, additional active-inductive resistance is put into the circuit of rotor winding, where the voltage drop from the rotor current is equivalent to the mentioned $\mathrm{EMFE}_{5}$. In this case, the value of the resistance significantly depends on the frequency of the rotor current [5]. In low slip modes of the machine, and therefore at a low rotor current frequency, a small resistance is introduced into the rotor circuit, so the rigidity of the mechanical characteristic, the power factor and the efficiency factor of the AM with the rotor of the proposed design is reduced insignificantly, compared to AM with a short-circuited female rotor. As the rotor speed of the AM female rotor decreases, and the sliding increases, a complex additional resistance with the predominance of the active component is automatically introduced into the rotor circuit, which leads to an increase in the electromagnetic moment of AM, while limiting the growth of the consumption current, and also to widening the control range. In this case, the necessary AM characteristics are obtained by choosing the appropriate geometric dimensions: the length and thickness of the sleeve.

At present, two methods for determining the parameters of the AM equivalent circuit with distributed secondary parameters is applied in practical calculations:

1. The calculation method, based on the classical works of Neumann on the theory of skin effect [5]. The advantage of these formulas is that they take into account both the impermanence of the magnetic permeability, and the loss of eddy currents and hysteresis. However, they are valid with sharp cases of the skin effect, when the cross dimensions of the magnetic circuit exceed twice depth at which the electromagnetic wave completely damps.

2. A calculation technique based on solving a system of differential equations of the electromagnetic field with finding the Pointing vector. The components of the complex Pointing vector is the flow of active and reactive power through a unit of surface. By the found active and reactive power, equivalent parameters of the equivalent circuit are determined.

In the study of electromagnetic processes in AM with a ferromagnetic sleeve on the rotor, the main attention is paid to the consideration of issues associated with the reflection of an electromagnetic wave from the outer surface of the sleeve, which has a thickness less than twice equivalent depth of penetration of the electromagnetic wave. The expediency of choosing such a sleeve thickness is explained by the fact that at this thickness it is 
possible to achieve high rigidity of the mechanical characteristic and the best energy parameters in the nominal mode [3].

The method based on solving a system of differential Maxwell equations makes it possible to calculate the electromagnetic field for any sleeve thickness, so we choose it for further calculations. In order to obtain a simple solution in the form of functional dependencies, the problem is solved in a rectangular coordinate system with the following assumptions:

- the magnetic permeability $\mu$ in the entire volume of the massive sleeve at the derivation of the main relations is assumed to be constant and only in the final formulas it is considered as a function of the magnetic field strength;

- the inner surface of the sleeve (Fig. 2) turns into a plane.

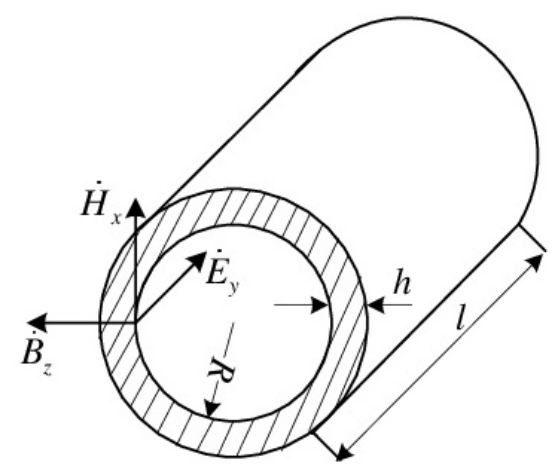

Figure 2. Surface of a ferromagnetic sleeve

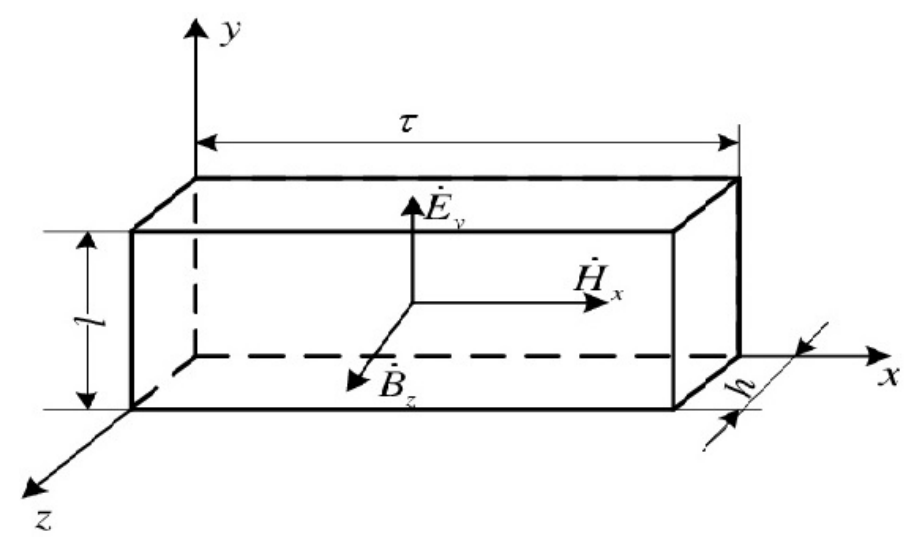

Figure 3. View of the surface of a ferromagnetic sleeve in a rectangular coordinate system

The base of the rectangular coordinate system is located on the inner surface of the massive sleeve: the $\mathrm{x}$ axis is directed along the circumference of the rotor, the $\mathrm{y}$ axis is parallel to the rotor axis, the $\mathrm{z}$ axis is along the radius (Fig. 3):

- the influence of higher harmonics is not taken into account;

- the short-circuited rotor winding is represented as an infinite current layer distributed on the surface of the steel of rotor body, the magnetic permeability of the rotor steel is assumed to be equal to infinite distance;

- in the coordinate system that is stationary relative to the AM rotor, the electric field strength is constant along the length of the sleeve, and along the coordinate $\mathrm{x}$ it varies according to the law:

$$
E_{y}(x, z, t)=E_{y m}(z) \cos \left(\omega t-\frac{\pi x}{\tau}\right),
$$

where $\omega$ - angular frequency of the rotor current; $\tau$ - pole pitch.

Substituting given equation into Maxwell system of differential equations and performing the transformations, we obtain following equation:

$$
\dot{E}_{y m}=A \cdot \operatorname{sh}(\lambda \cdot z)+B \cdot \operatorname{ch}(\lambda \cdot z),
$$


where $A$ and $B$ - constant integration,

$$
\lambda=\alpha(1+j), \alpha=\sqrt{\frac{\mu \omega \gamma}{2}}=\frac{1}{\delta_{M}},
$$

where $\delta_{M}$ - the equivalent depth of penetration of the electromagnetic wave into the sleeve in the direction of the $\mathrm{z}$ coordinate.

Constant integration is determined from the boundary conditions:

a) we assume that the tangential component of the magnetic field strength on the inner surface of the ferromagnetic sleeve $H_{s}$ is:

$$
A=\frac{j \omega \mu}{\alpha(1+j)} H_{s} ;
$$

b) the normal components of the induction of the magnetic field at the interface between the two environments (the outer surface of the ferromagnetic sleeve - air space) are equal to each other. Since the magnetic resistance of the air is much greater than the magnetic resistance of the sleeve, the normal component of the induction of the magnetic field on the outer surface of the massive sleeve must be zero, so:

$$
B=-\frac{j \omega \mu}{\alpha(1+j)} \operatorname{th}[\alpha(1+j) h] H_{s} .
$$

The total power of the electromagnetic field penetrating into the ferromagnetic sleeve through a unit of surface is:

$$
\dot{S}_{z}=S_{p}+j S_{q}=-\frac{1}{2}\left[\dot{E}_{y m} \cdot H_{x m}^{*}\right]_{z=0} .
$$

And the active and reactive components are determined accordingly:

$$
\begin{gathered}
S_{p}=\frac{1}{2} n \sqrt{\frac{\mu \omega}{2 \gamma}} H_{s}^{2} ; \\
S_{q}=\frac{1}{2} m \sqrt{\frac{\mu \omega}{2 \gamma}} H_{s}^{2},
\end{gathered}
$$

where $n$ and $m$ are coefficients that take into account the geometric dimensions of the ferromagnetic sleeve, $\gamma$ is electrical conductivity of steel.

$$
\begin{aligned}
& n=\frac{t h(\alpha h)+t g^{2}(\alpha h) \cdot t h(\alpha h)+t h^{2}(\alpha h) \cdot t g(\alpha h)-t g(\alpha h)}{1+t h^{2}(\alpha h) \cdot t g^{2}(\alpha h)} \\
& m=\frac{t h(\alpha h)+t g^{2}(\alpha h) \cdot t h(\alpha h)-t h^{2}(\alpha h) \cdot t g(\alpha h)+t g(\alpha h)}{1+t h^{2}(\alpha h) \cdot t g^{2}(\alpha h)} .
\end{aligned}
$$

Analytical expressions for the active and inductive resistances of the sleeve, which are equivalently introduced, are got in a result of solving the system of Maxwell equations under the condition of the constancy of the magnetic permeability

$\mu=$ const:

$$
\begin{aligned}
& r_{5}^{\prime}=4 n \sqrt{\frac{\mu_{0} \omega_{0}}{2 \gamma}} \cdot \sqrt{\mu_{s} s} \cdot \frac{m_{1}\left(k_{w 1} w_{1}\right)^{2}}{\pi d} \cdot l ; \\
& x_{5}^{\prime}=4 m \sqrt{\frac{\mu_{0} \omega_{0}}{2 \gamma}} \cdot \sqrt{\mu_{s} s} \cdot \frac{m_{1}\left(k_{w 1} w_{1}\right)^{2}}{\pi d} \cdot l,
\end{aligned}
$$

where $\mu_{0}$ - magnetic constant; $\omega_{0}$ - angular frequency of the current of the AM male rotor; $s-$ AM slip value, $m_{1} ; k_{w 1}, w_{1}$ - the number of phases, the winding factor, the number of turns of the winding of the AM male rotor; $\mu_{s}$ - relative magnetic permeability on the inner surface of the ferromagnetic sleeve, determined from the main magnetization curve from the value of the magnetic field strength on this surface $H_{s}$.

Final expressions for the determination of resistances, which are equivalently introduced, taking into account the effect of the impermanence of the magnetic permeability and hysteresis losses on the equivalent parameters 
of the sleeve, and also the effect of the edge effect are taken into account with the help of the corresponding coefficients:

$$
\begin{aligned}
& r_{5}^{\prime}=k \alpha_{p} n \cdot \sqrt{\mu_{s} s} \cdot l \cdot k_{e} ; \\
& x_{5}^{\prime}=k \alpha_{q} m \cdot \sqrt{\mu_{s} s} \cdot l \cdot k_{e},
\end{aligned}
$$

where $\alpha_{p} \alpha_{q}$-coefficients, that take into account the change in magnetic permeability in the sleeve and losses due to hysteresis; $k_{e}=1+\frac{d}{p l}-$ coefficient of edge effect; $p$ - number of pairs of AM poles.

$$
k=4 \sqrt{\frac{\mu_{0} \omega_{0}}{2 \gamma}} \cdot \frac{m_{1}\left(k_{w 1} w_{1}\right)^{2}}{\pi d} .
$$

So, the active and inductive resistances of the ferromagnetic sleeve, which are equivalently introduced, depend on the geometric dimensions of the sleeve, the relative magnetic permeability on its inner surface, the number of pole pairs and the AM slip.

In turn, the magnetic permeability $\mu_{s}$ depends on the strength of the magnetic field $H_{s}$, and hence on the value of the current of the female rotor $I_{2}^{\prime}$, which acts.

On the basis of the above calculation procedure for the parameters of the ferromagnetic sleeve, which are equivalently introduced, the sequence of calculating the static performance of an asynchronous machine of a special design can be described by the following algorithm (Fig. 4):

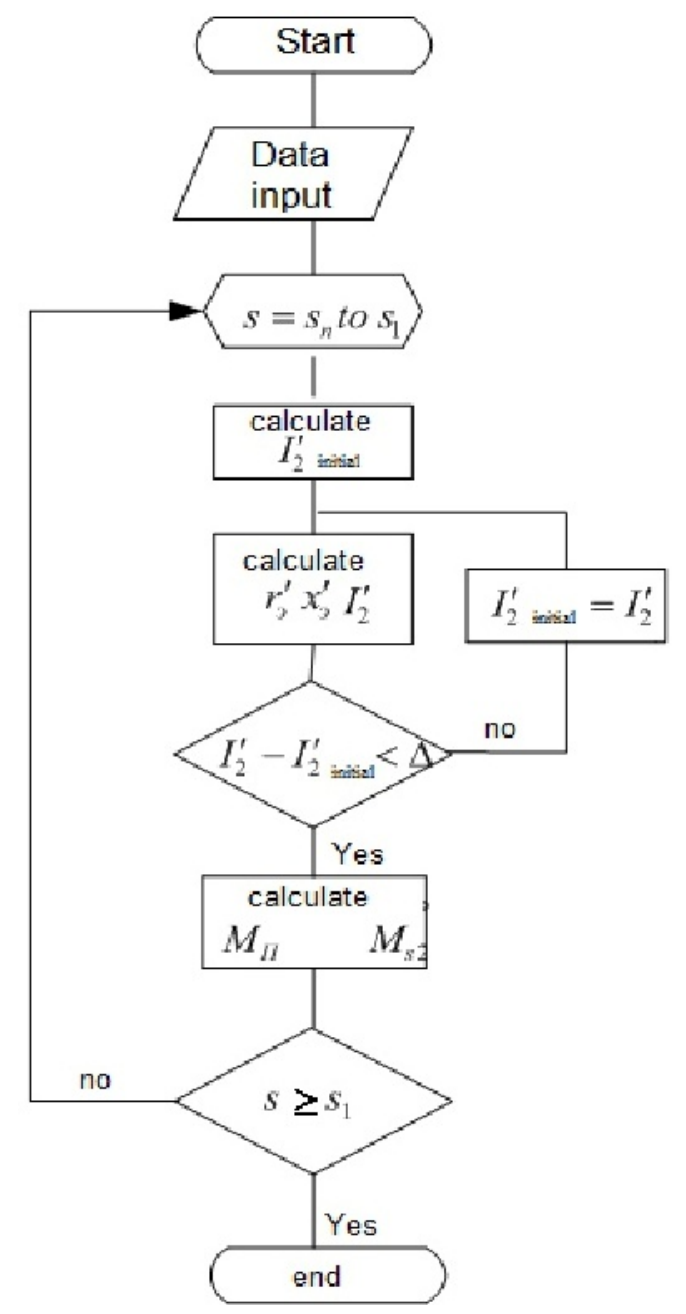

Figure 4. Algorithm for calculating the operating and starting characteristics of AM with a massive sleeve on the rotor 
1. We set the initial values of the slip $s_{\text {initial }}$ of AM, the axial length $l_{\text {initial }}$ and the radial thickness $h_{\text {initial }}$ of the ferromagnetic sleeve.

2. From the above formulas, we find the initial approximation of the current of the female rotor $I_{20}^{\prime}$ without taking into account the parameters of the sleeve $\left(z_{\text {equivalent }}^{\prime}=0\right)$.

3. Determine the magnetic field strength on the inner surface of a massive sleeve, taking into account the connection of the tangential component of the magnetic field strength on the inner surface of the sleeve and the value of the current of female rotor: $H_{s}=\sqrt{2} \cdot \frac{2 m_{1} k_{w 1} w_{1}}{\pi d} I_{2}^{\prime}$

4. With the magnetization curve of the sleeve material $\mu_{s}=f\left(H_{s}\right)$, we find the magnetic permeability $\mu_{s}$. In this case, it is expedient to use the approximated expression of the magnetization curve.

5 . The found value of the magnetic permeability, taking into account the parameters $\mathrm{n}$ and $\mathrm{m}$, determined from the above equations, correspond to the equivalent parameters of a massive sleeve $r_{e}^{\prime}$ and $x_{e}^{\prime}$.

6 . Calculate the current of the female rotor $I_{2}^{\prime}$, reduced to the winding of the male rotor, taking into account the parameters of the ferromagnetic sleeve found in paragraph 4.

7. Specify the initial approximation of the current of the female rotor and repeat the calculation of the parameters until the initial approximation and the calculated value of the current $I_{2}^{\prime}$ become equal to each other with the necessary accuracy.

8. Calculate the working and starting characteristics of AM.

9. Set the increment $\Delta s$ and perform the calculation of the characteristics for a given slip range.

When implementing the algorithm, it is assumed that the known values are: the number of pairs of poles of the synchronous and asynchronous machines, the number of turns and the winding coefficient of the male rotor, the parameters of the AM equivalent circuit, the coefficients of the curve for approximating the magnetization curve of the ferromagnetic sleeve material (in our case, the material is steel 3).

The calculation is performed for some slip points $\mathrm{s}$ in the range from $s_{\text {initial }}$ up to $s_{\text {max }}$ with increments $\Delta s$ each time for specific geometric dimensions of the sleeve. In accordance with the algorithm, the program is made and the calculation of characteristics is performed (Fig. 5).

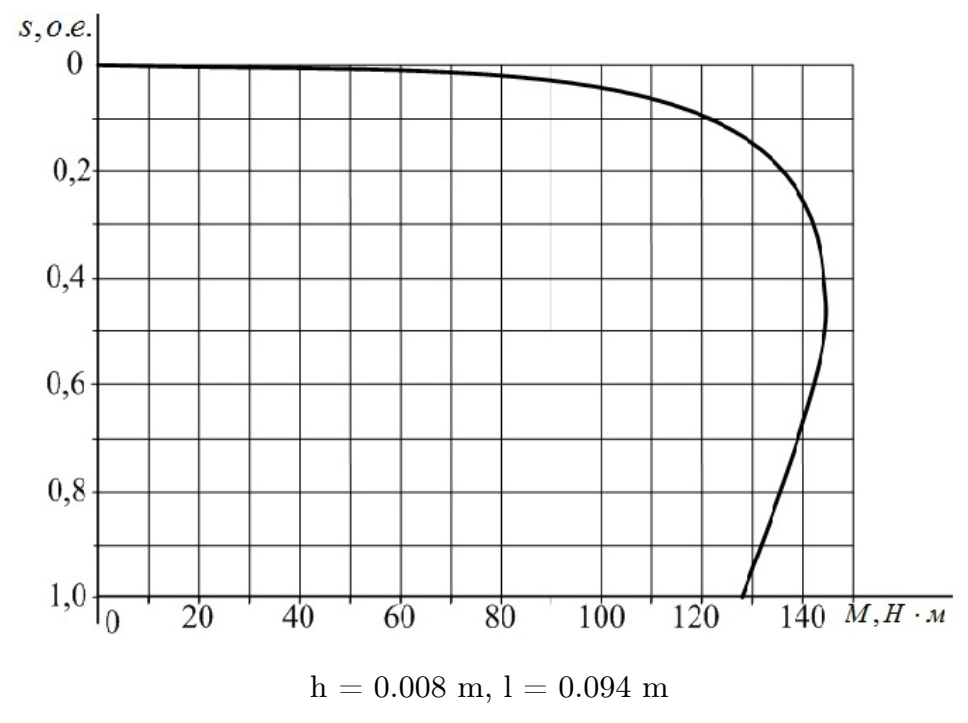

Figure 5. Mechanical characteristics of AM at a constant speed for the length and thickness of the ferromagnetic sleeve

The initial section of the graph (Fig. 5) for small slip is stiff, there is no pronounced maximum in the regulation zone. Analysis of the curve (Fig. 5) confirms the expediency of choosing an AM with a ferromagnetic sleeve on the female rotor. AM of such a design has good regulatory properties.

Calculated by the above methodic equivalent parameters of the ferromagnetic sleeve are shown on Figure 6 . 


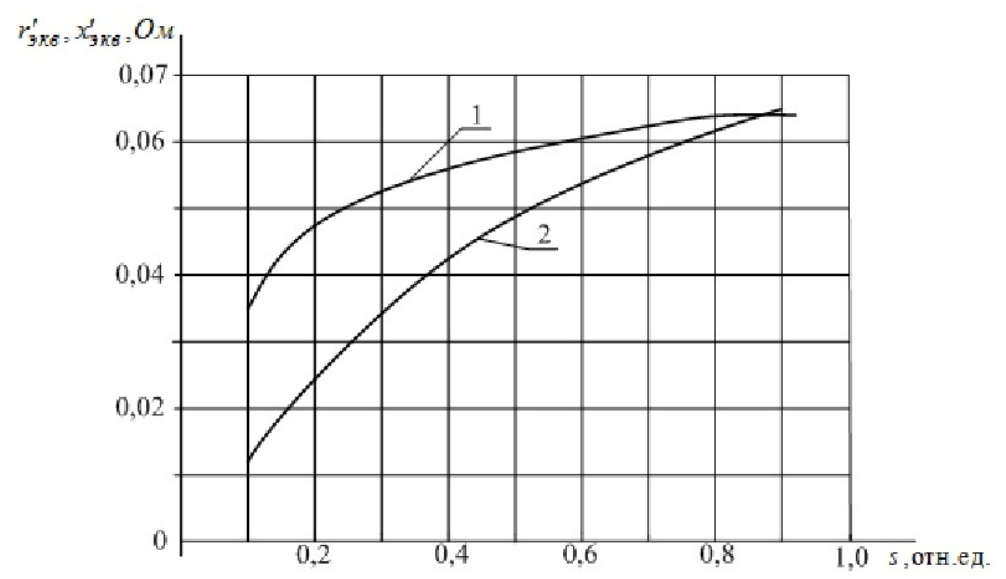

Figure 6 . The results of calculating the equivalent active (2) and inductive (1) resistances of a ferromagnetic sleeve with a length $l=0,11 \mathrm{~m}$ and thickness $h=0,008 \mathrm{~m}$

From the analysis of graphs (Fig. 6) it follows that the equivalent parameters of the ferromagnetic sleeve essentially depend on the AM slip value. For small AM slip, the parameters have small values and have an insignificant effect on the AM characteristics.

This allows to provide high rigidity of mechanical characteristics of AM. With an increase in the frequency of the rotor currents, a rapid rate of increase in the active component of the resistance is observed, which is equivalently introduced, in comparison with the inductive one, which provides an increase in the starting torque of AM.

\section{Conclusion}

The proposed method for calculating the parameters and characteristics of a ferromagnetic sleeve with the help of Maxwell differential equations allows simplify the development of asynchronous machines with a massive rotor. The developed algorithm for calculating the operating and starting characteristics of AM is expedient for use in the design of integral turbocharger systems of marine diesel engines.

\section{References}

1 Пахомов Ю.А. Судовые энергетические установки с двигателями внутреннего сгорания. - М.: ТрансЛист, 2007. -528 с.

2 Shiraishi K. (2010). Development of Large Marine Hybrid Turbocharger for Generating Electric Power with Exhaust Gas from the Main Engine / K. Shiraishi, Y. Ono, K. Sugishita. Mitsubishi Heavy Industries Technical Review. - Vol. 47. - 3, 53.

3 Лищенко А.И. Асинхронные машины с массивным ферромагнитным ротором / А.И. Лищенко, В.А. Лесник. - Киев: Наук. думка, 1984. - 168 с.

4 Корнилов Э.В. Системы газотурбинного наддува судовых дизелей / Э.В. Корнилов, П.В. Бойко. Одесса: Студия «Негоциант», 2006. - 224 с.

5 Могильников В.С. Асинхронные двигатели с двухслойным ротором и их применение / В.С. Могильников, А.М. Олейников, А.Н. Стрельников. - М.: Энергоатомиздат, 1983. - 120 с. 


\title{
С.В. Вороненко
}

\section{Асинхронды машиналардың көрсеткіштері мен параметрлерін арттыру мүмкіндіктерін зерттеу}

Кеме электр энергетикалық жүйелерінің үнемділігі мен сенімділігін арттыру қазіргі заманғы кеме жасаудың басым міндеті болып табылады. Бұл проблеманы шешу бағыттарының бірі - электр энергиясын өндіру үшін басты энергетикалық қондырғының қуатын пайдалану. Осы ретте асинхронды машиналарға өндірісте ең қарапайым және жұмыста сенімді ретінде артықшылық беру орынды. Сондай-ақ асинхронды машина нанотехнологияларды қолдана отырып, массивті ферромагниттік ротормен немесе гильзамен іске қосылуы мүмкін екенін атап өту қажет, бұл электр машиналары мен жалпы жүйенің энергетикалық параметрлері мен көрсеткіштерін арттыруға мүмкіндік береді. Мақалада ферромагнитті гильзасы бар қысқа тұйықталған роторы бар асинхронды машинаның (AM) құрылымы мен жұмысының ерекшеліктеріне талдау жүргізілді. Гильзаның геометриялық өлшемдеріне АМ параметрлері мен сипаттамаларының тәуелділігі көрсетілген, оларды Максвелл дифференциалдық теңдеулер жүйесін қолдану арқылы анықтау әдістемесі ұсынылған. Машина мен ферромагниттік гильзаның эквивалентті параметрлерін есептеу алгоритмі әзірленді.

Kiлm сөздер: асинхронды машина, ротор, ферромагниттік гильза, сырғу, белсенді және индуктивті кедергіге балама.

\section{С.В. Вороненко}

\section{Исследование возможностей повышения показателей и параметров асинхронных машин}

\begin{abstract}
Повышение экономичности и надежности судовых электроэнергетических систем является приоритетной задачей современного судостроения. Одним из направлений решения данной проблемы является использование мощности главной энергетической установки для производства электроэнергии. При этом предпочтение целесообразно отдавать асинхронным машинам как наиболее простым в производстве и надежным в работе. Необходимо отметить также то, что асинхронная машина может быть выполнена с массивным ферромагнитным ротором или гильзой с применением нанотехнологий, что позволит повысить энергетические параметры и показатели электрической машины и системы в целом. В статье проведен анализ особенностей устройства и работы асинхронной машины $(\mathrm{AM})$ с короткозамкнутым ротором с ферромагнитной гильзой. Показана зависимость параметров и характеристик AM от геометрических размеров гильзы, предложена методика их определения с использованием системы дифференциальных уравнений Максвелла. Разработан алгоритм расчета характеристик AM машины и эквивалентных параметров ферромагнитной гильзы.
\end{abstract}

Ключевые слова: асинхронная машина, ротор, ферромагнитная гильза, скольжение, эквивалентные активное и индуктивное сопротивления.

\section{References}

1 Pakhomov, Iu.A. (2007). Sudovye enerheticheskie ustanovki s dvihateliami vnutrenneho shoraniia /Ship power plants with internal combustion engines]. Moscow: TransLit [in Russian].

2 Shiraishi, K., Ono, Y., \& Sugishita, K. (2010). Development of Large Marine Hybrid Turbocharger for Generating Electric Power with Exhaust Gas from the Main Engine. Mitsubishi Heavy Industries Technical Review, Vol 47, 3, 53.

3 Lishchenko, A.I., \& Lesnik, V.A. (1984). Asinkhronnye mashiny s massivnym ferromahnitnym rotorom [Asynchronous machines with a massive ferromagnetic rotor]. Kiev: Naukova dumka [in Russian].

4 Kornilov, E.V., \& Boiko, P.V. (2006). Sistemy hazoturbinnoho nadduva sudovykh dizelei: osnovy teorii, ekspluatatsiia, konstruktsii, remont /Gas turbine supercharging systems for ship diesel engines: theory basis, operation, construction, repair]. Odessa: Studiia «Negotsiant» [in Russian].

5 Mogilnikov, B.C., Oleinikov, A.M., \& Strelnikov, A.N. (1983). Asinkhronnye dvihateli s dvukhsloinym rotorom [Asynchronous motors with double-layer rotor]. Moscow: Enerhoatomizdat [in Russian]. 